\title{
REGIONAL ROCKBURST INIDICATOR FOR STRUCTURAL UNITS OF UPPER SILESIA COAL BASIN
}

\author{
RENATA PATYŃSKA \\ Department of Rockburst and Rock Mechanics, Central Mining Institute, pl. Gwarków 1, 40-166 Katowice, Poland, \\ Phone: 32 2592474, Mob.: 48 602291144, Fax: 32 2596533, corresponding author, e-mail: r.patynska@gig.eu
}

KRYSTYNA STEC

Central Mining Institute, Department of Geology and Geophysics, pl. Gwarków 1, 40-166 Katowice, Poland

\begin{abstract}
The paper presents the characteristics of seismic tremors and rockbursts that occurred between 2001 and 2015 . The characteristics are based on a general description of the geological structure of the Upper Silesian Coal Basin (USCB). The level of seismic activity in the analysed period changed a number of times and depended on the intensity of mining works and diverse mining and geological conditions in each of the five regions where tremors occurred (Bytom Trough, Main Saddle, Main Trough, Kazimierz Trough, and Jejkowice and Chwałowice Troughs) and which belong to various structural units of the Upper Silesia. It was found out that in the case of rockbursts the phenomena were recorded in three regions. These are: Main Saddle, Bytom Trough, and Jejkowice and Chwałowice Troughs. The so called Regional Rockburst Indicator (RWT) was estimated for each of the regions where the rockbursts had been recorded. The obtained values of RWT are presented against the Probability of RockBurst (PT) in a given area.
\end{abstract}

Key words: mining excavation, tremors, rockburst

\section{INTRODUCTION}

The mining exploitation of coal deposits in the Upper Silesian Coal Basin (USCB) causes an imbalance in the distribution of the rock mass stress and tension, both in the immediate and distant surroundings of mine workings. The consequence of this process includes, among other things, the occurrence of seismic rock mass tremors. These phenomena are monitored by two independent recording systems: a mining seismological network and a regional system - Upper Silesian Seismological Network (USSN) which belongs to the Central Mining Institute. A catalogue of strong tremors of energy $E \geq 10^{5} \mathrm{~J}$, based on the recordings obtained from USSN, has been kept since 1974. The catalogue contains seismological parameters of more than 59200 tremors [9]. Some of the seismic tremors were the direct cause of rockbursts, which consequently caused damage and/or destruction of drifts, and dangerous and often fatal accidents among miners. The detailed characteristics of all cases of rockbursts is included in the catalogue of rockburst stored in the archives of the Central Mining Institute. The rockburst database, kept since 1949, consists of documents that form the basis of utilitarian data (mining and geological parameters, scale of consequences) describing all the cases of 3,935 rockbursts [6].

The article presents the characteristics of seismic tremors and rockbursts that occurred between 2001 and 2015. The characteristics are presented against a general description of the geological structure of USCB and based on the data offered by the catalogue of tremors and rockbursts. The analysis showed that the level of seismic activity that occurred in several regions of USCB, corresponding to the structural units (Bytom Trough, Main Saddle, Main Trough, Kazimierz Trough, and Jejkowice and Chwałowice Troughs), was subject to changes during the analysed period and depended both on the intensity of the mining works and various mining and geological conditions of a given area. It was found out that the cases of rockbursts were recorded only in three regions. These are: Main Saddle, Bytom Trough, and Jejkowice and Chwałowice Troughs. Therefore, so-called Regional Rockburst Indicator (RWT) was calculated for each of them, later correlated with average depths of rockbursts, and finally presented against the Probability of RockBurst (PT) in a given region. 


\section{CHARACTERISTICS OF STRUCTURAL UNITS OF UPPER SILESIA COAL BASIN}

The Upper Silesian Coal Basin is located in the Upper Silesian Block, the Brunovistulicum tectonic unit. The tectonic structure of the area developed mainly during the Leonina Variscan orogeny and is characterized by numerous folds and troughs, thrusts and faults. Several structures were separated within the Upper Silesian Block, they are characterized by subparallel arrangement and are separated by second order discontinuities [1] including: Upper Silesian Trough, Upper Silesian series of folds, Moravian-Silesian fold and thrust zone, Bielsko-Biała Dome, Rzeszotary Horst, Liplas Trough (Fig. 1).

The northern part of USCB lies within the Upper Silesian fold zone, called the zone of fold and block tectonics [2]. It includes the following structural units: Bytom Trough, Kazimierz Trough and Main Saddle.

Bytom Trough is an area of complex structure. It consists of a series of shallow Brach synclines, separated by dome-shaped upthrust running north-west -south-east (NW-SE). Such a trough is asymmetrical. Its latitudinal axis runs from the west (W) to the east (E) near the north-eastern wing. This Such location of the axis means that the northern wing is characterised by smaller dip angles (up to $17^{\circ}$ to the south) in relation to the opposite southern wing, where the dip angle locally reaches even $50^{\circ}$. This complicated structure of the trough is also disturbed by a network of faults, running mainly $\mathrm{NW}-\mathrm{SE}$, and perpendicular to them, with different throws and various angles of fault planes.

Main Saddle is the most important element of the tectonic northern part of USCB after the Bytom Trough. Its structure is made of a series of elevations cut by transverse elevations, creating a series of "domes" stretching from west to east. There is a number of fault structures within the Main Saddle, the largest of which is the Kłodnica Fault. It runs parallel and has a variable amplitude of throws and a variable angle of inclination of the fault plane. This structure throws layers to the south. The amplitude of a throw varies from $360 \mathrm{~m}$ in the east, then decreases towards the west to about $20 \mathrm{~m}$. The Kłodnica Fault is accompanied by a number of smaller faults of throws from a few to several meters, arranged stepwise or in a fanlike manner, and faults running from north-east to south-west with throws from a dozen to several dozen meters. The network multidirectional faults of lower order, accompanying the Kłodnica Fault, resulted in cutting the researched area into a number of tectonic blocks of different sizes, of different situation to each other, both vertically and horizontally. In consequence, this area is highly vulnerable to any kind of deformation resulting from past and present mining activity.

Kazimierz Trough located in the north-eastern part of the coal basin is an asymmetric structure running NNW-SSE. Its northern wing has a variable

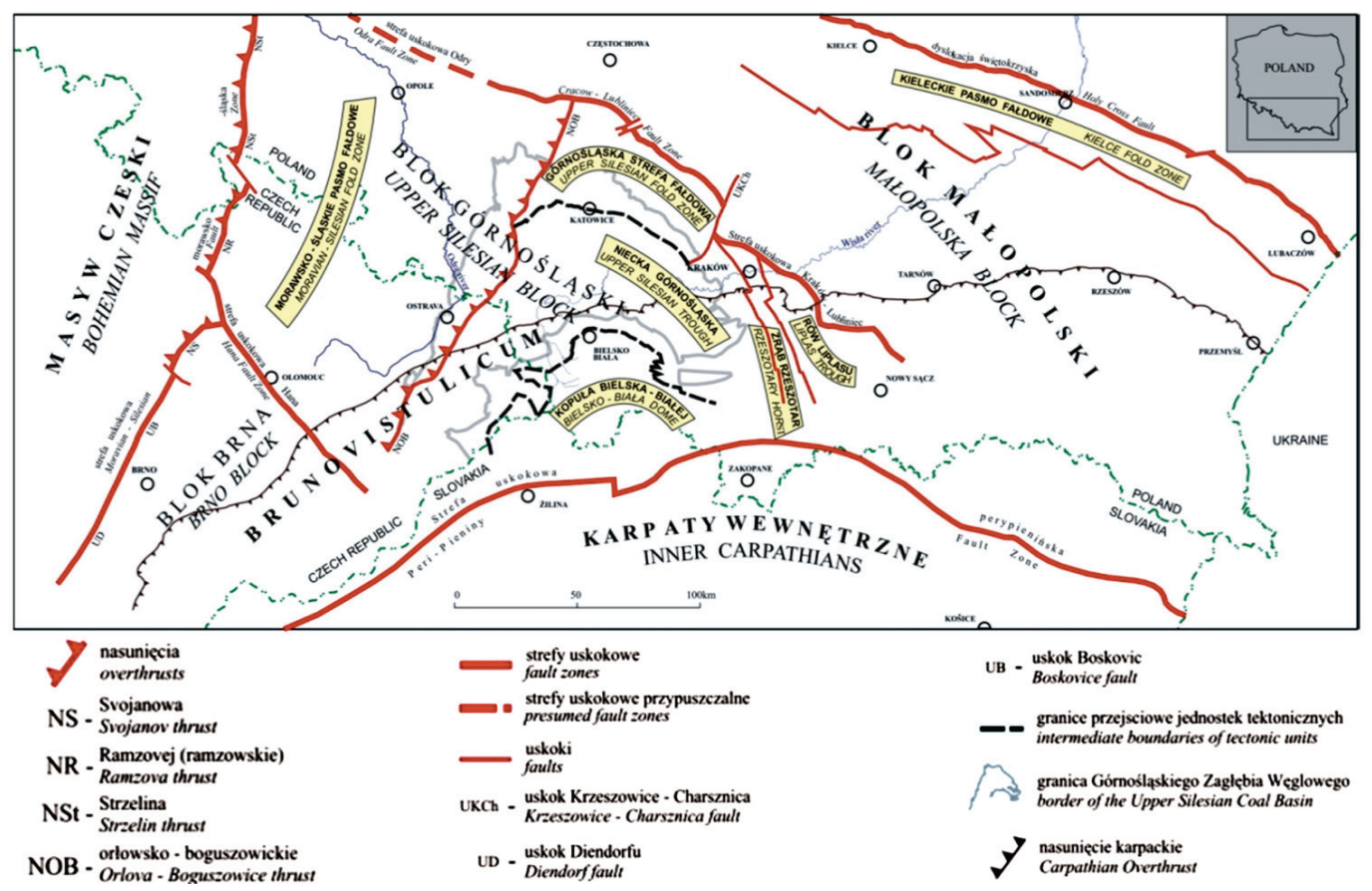

Fig. 1. The outline of the structural units of Upper Silesian Coal Basin (Buła, Żaba, Habryn, 2008) 
inclination, from mild to steep, the south slope is mild. The layers run approximately parallel to the axis of the trough, their inclination is variable and ranges from 15 to $45^{\circ}$.

The central and south-eastern part of USCB is the Upper Silesian Trough (disjunctive tectonic zone). The largest area of this zone is the Main Trough. It is the most extensive structure of USCB. It is a very gentle and extensive syncline with a layer dip from 0 to $10^{\circ}$. Its main structural elements include a number of faults of varying amplitude of throws, often above $1000 \mathrm{~m}$, and mild bending of layers in the form of domes, anticlinal faults or troughs and synclines. The faults are mostly of regular throw and throw-slip kind, rarely only slip. The length of fault zones is not equal and ranges from a few meters to several dozen kilometres. Similarly, the orientation of faults varies from the latitudinal faults to the meridian, the latitudinal faults are characterized also by substantial throws, accumulated mainly in the central and southern parts of the trough. Due to the fact that they throw rock mass to the south, the structure of the throw is stepwise, whereas the meridional faults are located almost all over the area, and the NW-SE faults could be found only along the $\mathrm{NE}$ and $\mathrm{E}$ border.

The western part of USCB is a part of the Moravian-Silesian fold and thrust zone (fold tectonic zone) and its width is $20 \mathrm{~km}$. The following structural units are included within this area: Jejkowice Trough, Michałkowice Fold, Chwałowice Trough and Orlów Fold. The folds are directed towards the east. The reduced intensity of the folds can be observed in the region, from the outside to the centre of the basin. In the north-west the fold tectonic structures turn their direction and run to the north-east and became westeastern structures. It is associated with slip movements in the ground along the northern Bytom floe split. This zone is characterised mainly by regular or throw-slip faults, and some elevations and crosswise depressions. The elevation comprises complicated folds, thrusts and reverse faults, whereas pairs of flat troughs are located in depressions.

\section{CHARACTERISTICS OF SEISMIC ACTIVITY OF UPPER SILESIAN COAL BASIN}

The systematic observation of high-energy seismic activity induced by mining activities of coal mines in the Upper Silesian Coal Basin, has been carried since the 1950s. Initially, the records of seismic tremors were taken based on a number of individual seismic

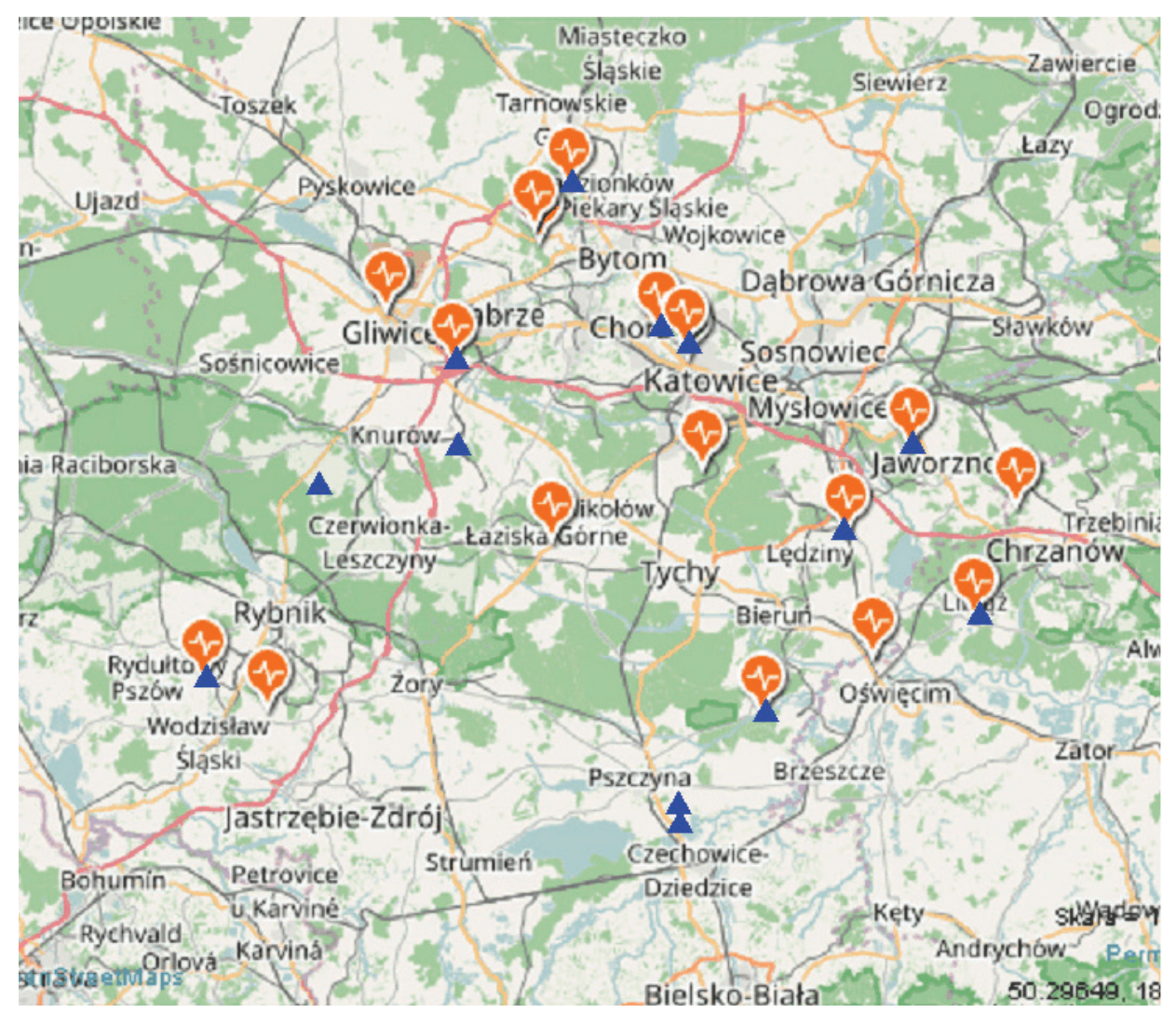

Fig. 2. Location of Upper Silesian Seismological Network in 2015 (www.grss.gig.eu/pl/) 
stations. Since 1974, the observation of seismic activity of $E \geq 10^{5} \mathrm{~J}$ energy has been conducted by Upper Silesian Seismological Network (USSN) ([4], [10]) which includes several stations located in USCB, and a records centre in the Central Mining Institute in Katowice. USSN operates in a monitoring mode based on continuous recording of tremors, and tremor automatic detection mode detecting seismic occurrences above a set threshold. Seismic signals received from individual seismometer stations located in USCB are sent to the records centre in Central Mining Institute. The location of stations operating in 2015 are shown in Fig. 2.

The catalogue of rock mass tremors of $E \geq 10^{5} \mathrm{~J}$ energy was developed based on seismograms, and contains basic parameters, such as: date and time of an event, tremor energy, local magnitude, name of the mine, the coordinates of the epicentre, the name of the seam, and excavation. On the basis of the analysis of the tremor catalogue, it was found out that the outbreaks of tremors did not occur uniformly throughout the whole area of the Upper Silesian Coal Basin but were concentrated in five areas belonging to different structural units, especially in areas where coal seams are deposited deep, and rock layers are characterized by a large share of layers of sandstone and strongly developed tectonics. They are: Bytom Trough, Main Saddle, Kazimierz Trough, and Jejkowice and Chwałowice Troughs [4].
The following list contains data from 2001 to 2015. During this period, the seismic intensity varied. The seismic activity included both low-energy tremors, unnoticeable on the surface, and high-energy events with characteristics similar to a weak earthquake (Fig. 3).

Seismic activity in the areas of mines where currently no mining exploitation is carried out, does not occur. On the other hand, recorded seismic activity in active mines decreases as the conditions of mining works deteriorated. The most frequently mentioned causes include: increasing depth of exploitation, operation in fault zones and within the zones of protective pillars and near edges and caving zones.

In total, 17,985 tremors of $E \geq 10^{5} \mathrm{~J}$ energy during this period were recorded, including 14,824 events of energy $10^{5} \mathrm{~J}, 2,80110^{6} \mathrm{~J}, 333$ tremors of $10^{7} \mathrm{~J}$, and 23 with energy of $10^{8} \mathrm{~J}$. Four events were characterized by an energy of $10^{9} \mathrm{~J}$. The location of outbreaks of tremors is shown in Fig. 3, and a list of energy levels and quantity in different structural units of USCB is presented in Table 1.

Table 1 shows that the area characterised by the greatest seismic activity was the Kłodnica Fault and the associated faults in the Main Saddle. The seismic activity in this region was mainly related to the mining operation carried out in Ruda and Saddle layers (seams $418,502,510)$. They are characterized by alternating rudaceous, medium and close-grained sand-

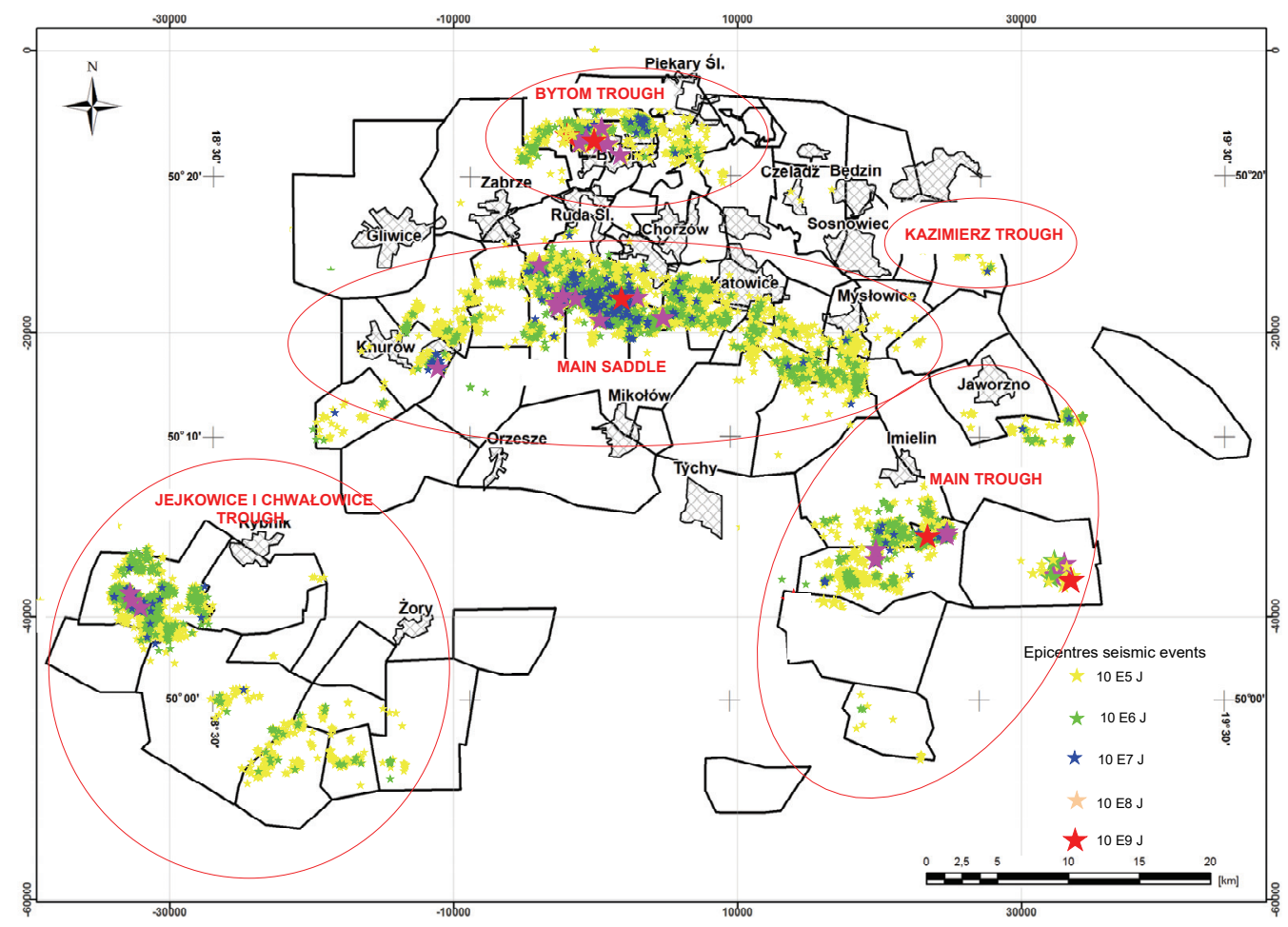

Fig. 3. Location of epicentres seismic events in USCB between 2001 and 2015 against the background of the mining areas 
Table 1. List of tremors between 2001 and 2015 in the structural units of USCB

\begin{tabular}{|l|c|c|c|c|c|}
\hline \multicolumn{1}{|c|}{ Area } & $\begin{array}{c}\text { Number } \\
\text { of tremors } \\
\text { NT }\end{array}$ & $\begin{array}{c}\text { Percentage } \\
\text { share } \\
{[\%]}\end{array}$ & $\begin{array}{c}\text { Tremor } \\
\text { total energy ET } \\
{[\mathrm{J}]}\end{array}$ & $\begin{array}{c}\text { Percentage } \\
\text { share } \\
{[\%]}\end{array}$ & $\begin{array}{c}\text { Tremor average } \\
\text { energy } \\
{[\mathrm{J}]}\end{array}$ \\
\hline Bytom Trough & 1492 & 8.3 & $5.48 \cdot 10^{9}$ & 12.2 & $2.17 \cdot 10^{6}$ \\
\hline Main Saddle & 8164 & 45.4 & $2.04 \cdot 10^{10}$ & 45.3 & $2.06 \cdot 10^{6}$ \\
\hline Main Trough & 5321 & 26.6 & $1.35 \cdot 10^{10}$ & 30.1 & $1.92 \cdot 10^{6}$ \\
\hline Jejkowice and Chwałowice Trough & 2991 & 16.6 & $5.55 \cdot 10^{9}$ & 12.4 & $1.45 \cdot 10^{6}$ \\
\hline Kazimierz Trough & 17 & 0.1 & $3.36 \cdot 10^{7}$ & 0.1 & $1.26 \cdot 10^{6}$ \\
\hline
\end{tabular}

stone shoals, among which coal seams, siltstones and mudstones occur. These are potential layers that may induce seismic activity in the structural unit, and they are sandstone layers with a thicknesses of 10 to $30 \mathrm{~m}$, and the uniaxial compression capacity of 48 to $92 \mathrm{MPa}$. Moreover, numerous faults with substantial throws (Kłodnica Fault and associated faults) occur in this region, and consequently they had greatly influenced the level of seismic activity. The greatest number of tremors was recorded in this area (8164 events), which represents $45.4 \%$ of the events in the whole Upper Silesian Coal Basin. The total seismic energy released by these tremors amounted to $2.035 \cdot 10^{10} \mathrm{~J}$, which is $45.3 \%$. The region was characterised by an average energy of $2.063 \cdot 10^{6} \mathrm{~J}$. A tremor of $4 \cdot 10^{9} \mathrm{~J}$ energy was recorded in 2015 - the strongest so far in USCB.

The region with the second highest number of high-energy events was the Main Trough. Despite the large number and high-energy tremors in this region, no rockbursts have been recorded in this area. It should be emphasized that the layers of sandstone in this region are characterized by large thickness between $30-100 \mathrm{~m}$, but at the same time their uniaxial compressive strength is poor and ranges from 16 to $30 \mathrm{MPa}$ (an average of $20 \mathrm{MPa}$ ). This clearly indicates that these deposits should not be able to generate high-energy tremors. The analysis shows, however, that tremors of $10^{7}-10^{9} \mathrm{~J}$ energy occurred in the mines located within the Main Trough, mostly during the exploitation of Laziska layers. The seams with the highest level of seismic activity included seams 207 and 209. The outbreaks of tremors were located at a considerable distance above the exploited seams, mainly in the vicinity of present tectonic structures. Generally, 5,321 tremors occurred between 2001 and 2015 in the Main Trough, which is $26.6 \%$. Total energy of tremors in the Main Trough amounted to $1.352 \cdot 10^{10} \mathrm{~J}(30.1 \%)$, and the average energy of tremors was $1.92 \cdot 10^{6} \mathrm{~J}$. It was characteristic of the Main Trough that the seismic activity began to occur in the 1980s and in recent years it has grown rapidly.
It should be noted that the strongest tremor which has been recorded in the region, $3 \cdot 10^{9} \mathrm{~J}$ energy, occurred in 2010 during the operation of seam 207.

The region of the Jejkowice and Chwałowice Troughs was also characterized by high levels of seismic activity, in the areas where the exploitation of Jejkowice layers, mainly seams 703 and 713, caused the biggest number of tremors in this area. In the investigated period 1,991 tremors $(16.6 \%)$ of total energy $5.551 \cdot 10^{9} \mathrm{~J}(12.4 \%)$ occurred. The average energy of tremors was slightly lower than the average energy in the Main Trough. The essential influence on the growth of seismic activity in this region was the occurrence of sandstone layers with large thickness and uniaxial compression bearing capacity, on average about $75 \mathrm{MPa}$, deposited at large distances ranging from 200 to $300 \mathrm{~m}$ from the mining activity area. The impact of the exploitation on the number of seams below these layers is summed up, and in consequence they are destructed and deflected, which results in the generation of high-energy tremors with energy of $10^{7} \mathrm{~J}$ and $10^{8} \mathrm{~J}$.

By comparison, 1492 (8.3\%) tremors occurred in the Bytom Trough, $12.2 \%$ of the total energy. The average energy was high and reached $2,166 \cdot 10^{6} \mathrm{~J}$. The strongest tremor of energy greater than $10^{9} \mathrm{~J}$ occurred in the axis of the Bytom Trough [5]. This region, similarly to the Main Saddle, is characterized by alternating rudaceous, medium and closegrained sandstone shoals, among which coal seams, siltstones and mudstones occur. The seismic activity of the rock mass in the area of the Bytom Trough occurred mainly during the mining operation carried out in the saddle, Ruda and Poręba layers.

The above data allow to conclude that the Kazimierz Trough was characterized by low seismic activity, with a small number of tremors, representing about $0.1 \%$ of the events in the entire Upper Silesian Coal Basin. The data indicate that this low activity was associated with the decreasing range of mining operation in the region. 


\section{ROCKBURST HAZARD IN THE LIGHT OF SEISMIC ACTIVITY BETWEEN 2001 AND 2015}

Seismic tremors which resulted in rockbursts, are one of the main threats to safety at work and the continuity of mining production. The most dangerous ones include tremors causing damage to excavations and resulting in accidents (serious and fatal) among miners working within the reach of seismic events. The analysis of tremor protocols indicates that there have been instances of tremors recorded in recent years resulting in consequences similar to mining disasters [6].

The largest number of tremors between 2001 and 2015 occurred during the exploitation of seams deposited in the north and central wing of the Main Saddle (Table 2). Among all of the 42 recorded events, 28 rockbursts occurred in this area (64\%). These rockbursts

Table 2. List of parameters of tremors occurred between 2001 and 2015 in USCB

\begin{tabular}{|c|c|c|c|c|c|}
\hline Item No. & Mine/date & Seam & $\begin{array}{l}\text { Rockburst } \\
\text { energy Et, J }\end{array}$ & $\begin{array}{c}\text { Seam } \\
\text { depth } \mathrm{H}, \mathrm{m}\end{array}$ & Structural unit \\
\hline 1 & Wujek Ruch Śląsk, 18 Apr. 2015 & 409 & $4 \cdot 10^{9}$ & 1069 & Main Saddle \\
\hline 2 & Halemba Wirek, 22 Dec. 2015 & $504 / \mathrm{H}$ & $6 \cdot 10^{6} / 9 \cdot 10^{6}$ & 800 & Main Saddle \\
\hline 3 & $\begin{array}{l}\text { Borynia - Zofiówka - Jastrzębie, } \\
\text { 19 June } 2014\end{array}$ & $409 / 3$ & $8.5 \cdot 10^{7}$ & 950 & Jejkowice and Chwałowice Troughs \\
\hline 4 & Piekary, 6 Nov. 2013 & $510 /$ III & $3 \cdot 10^{7}$ & 720 & Bytom Trough \\
\hline 5 & Marcel, 8 March 2012 & $703 / 1-2-705 / 1$ & $9.2 \cdot 10^{7}$ & 890 & Jejkowice and Chwałowice Troughs \\
\hline 6 & JAS-MOS, 28 Jan. 2011 & $510 / 2$ & $2.3 \cdot 10^{6}$ & 983 & Jejkowice and Chwałowice Troughs \\
\hline 7 & Mysłowice-Wesoła, 29 Jan. 2011 & $501 / 1$ & $9 \cdot 10^{5}$ & 600 & Main Saddle \\
\hline 8 & Borynia - Zofiówka, 10 Feb. 2011 & $409 / 3$ & $3.9 \cdot 10^{6}$ & 950 & Jejkowice and Chwałowice Troughs \\
\hline 9 & Bobrek - Centrum, 19 July 2011 & 510 & $8 \cdot 10^{6}$ & 585 & Bytom Trough \\
\hline 10 & Rydułtowy - Anna, 21 Oct. 2010 & $713 / 1-2+712 / 1-2$ & $7 \cdot 10^{5}$ & 1140 & Jejkowice and Chwałowice Troughs \\
\hline 11 & Rydułtowy - Anna, 24 March 2010 & $713 / 1-2+712 / 1-2$ & $1.9 \cdot 10^{6}$ & 1140 & Jejkowice and Chwałowice Troughs \\
\hline 12 & Bielszowice, 5 Oct. 2009 & $405 / 2$ & $3 \cdot 10^{7}$ & 1050 & Main Saddle \\
\hline 13 & Staszic, 23 Feb. 2008 & 501 & $2 \cdot 10^{7}$ & 930 & Main Saddle \\
\hline 14 & Wujek, 16 Apr. 2008 & 502 & $9 \cdot 10^{7}$ & 630 & Main Saddle \\
\hline 15 & Bielszowice, 24 July 2008 & 510 & $8 \cdot 10^{5}$ & 840 & Main Saddle \\
\hline 16 & Mysłowice - Wesoła, 11 Sep. 2008 & 510 & $8 \cdot 10^{5}$ & 550 & Main Saddle \\
\hline 17 & Halemba - Wirek, 21 Nov. 2008 & 504 & $1 \cdot 10^{7}$ & 600 & Main Saddle \\
\hline 18 & Zofiówka, 10 Apr. 2007 & $409 / 3$ & $1 \cdot 10^{6}$ & 966 & Jejkowice and Chwałowice Troughs \\
\hline 19 & JAS-MOS, 25 Apr. 2007 & $510 / 1$ & $2 \cdot 10^{5}$ & 970 & Jejkowice and Chwałowice Troughs \\
\hline 20 & Pokój, 19 July 2007 & 502 & $8 \cdot 10^{7}$ & 730 & Main Saddle \\
\hline 21 & Halemba, 22 Feb. 2006 & 506 & $2 \cdot 10^{8}$ & 910 & Main Saddle \\
\hline 22 & Rydułtowy Anna, 13 May 2006 & $703 / 1$ & $1 \cdot 10^{8}$ & 1050 & Jejkowice and Chwałowice Troughs \\
\hline 23 & Pokój, 27 July 2006 & 502 & $9 \cdot 10^{7}$ & 970 & Main Saddle \\
\hline 24 & Rydułtowy-Anna, 19 Dec. 2006 & $703 / 1$ & $9 \cdot 10^{7}$ & 1050 & Jejkowice and Chwałowice Troughs \\
\hline 25 & Bielszowice, 27 Jan. 2005 & 502 & $1 \cdot 10^{7}$ & 890 & Main Saddle \\
\hline 26 & Bobrek-Centrum, 22 Aug. 2005 & 510 upper layer & $2 \cdot 10^{6}$ & 690 & Bytom Trough \\
\hline 27 & Pokój, 25 Nov. 2005 & 418 & $1 \cdot 10^{7}$ & 745 & Main Saddle \\
\hline 28 & Halemba, 22 Jan. 2004 & $415 / 1$ & $9 \cdot 10^{7}$ & 770 & Main Saddle \\
\hline 29 & Halemba, 11 Feb. 2004 & $415 / 1$ & $9 \cdot 10^{5}$ & 770 & Main Saddle \\
\hline 30 & Polska - Wirek, 20 Sep. 2004 & 502 & $3 \cdot 10^{7}$ & 711 & Main Saddle \\
\hline 31 & Katowice - Kleofas, 04 Mar. 2003 & 510 & $2 \cdot 10^{7}$ & 620 & Main Saddle \\
\hline 32 & Wesoła, 24 Mar. 2003 & $501 \mathrm{~B}$ & $2 \cdot 10^{6}$ & 760 & Main Saddle \\
\hline 33 & Wujek, 18 Aug. 2003 & 510 & $2 \cdot 10^{6}$ & 750 & Main Saddle \\
\hline 34 & Wujek, 10 Sep. 2003 & 510 & $4 \cdot 10^{6}$ & 760 & Main Saddle \\
\hline 35 & Sośnica, 8 Jan. 2002 & 504 & $6 \cdot 10^{5}$ & 700 & Main Saddle \\
\hline 36 & Śląsk, 25 Jan. 2002 & $502 / \mathrm{J}$ & $6 \cdot 10^{7}$ & 910 & Main Saddle \\
\hline 37 & Wesoła, 9 Aug. 2002 & 501 & $4 \cdot 10^{6}$ & 760 & Main Saddle \\
\hline 38 & Bielszowice, 7 Sep. 2002 & $405 / 2$ & $5 \cdot 10^{5}$ & 1150 & Main Saddle \\
\hline 39 & Anna, 5 Feb. 2001 & $630 / 2$ & $6.6 \cdot 10^{5}$ & 930 & Main Saddle \\
\hline 40 & Katowice-Kleofas, 15 Feb. 2001 & $510 / \mathrm{II}$ & $1 \cdot 10^{7}$ & 660 & Main Saddle \\
\hline 41 & ZG Bytom II, 26 June 2001 & 510 & $2 \cdot 10^{5}$ & 930 & Bytom Trough \\
\hline 42 & Wesoła, 14 Sep. 2010 & 501 & $8 \cdot 10^{6}$ & 820 & Main Saddle \\
\hline
\end{tabular}


were primarily related to the mining operation carried out in seams categorized as saddle 500, deposited in fault zones among thick and strong rock layers. The next two areas with a large number of rockbursts include the Jejkowice and Chwałowice Troughs, 10 reported events (26\%), and the Bytom Trough, 4 rockbursts $(10 \%)$.

a) Tremor energy $10^{5} \leq E \leq 10^{9}$

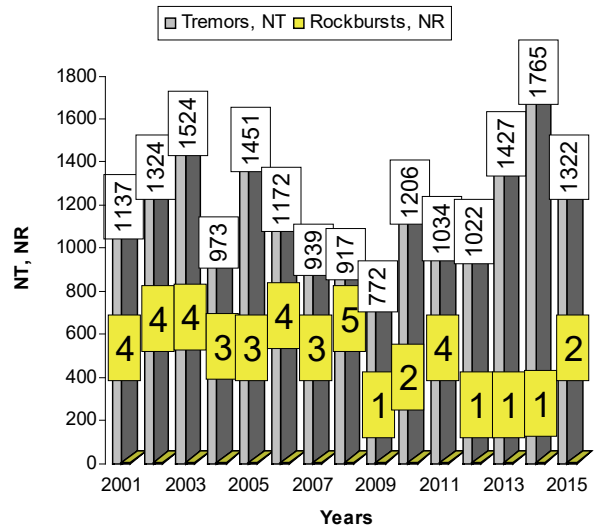

c) Tremor energy $10^{6} \leq E<10^{7}$

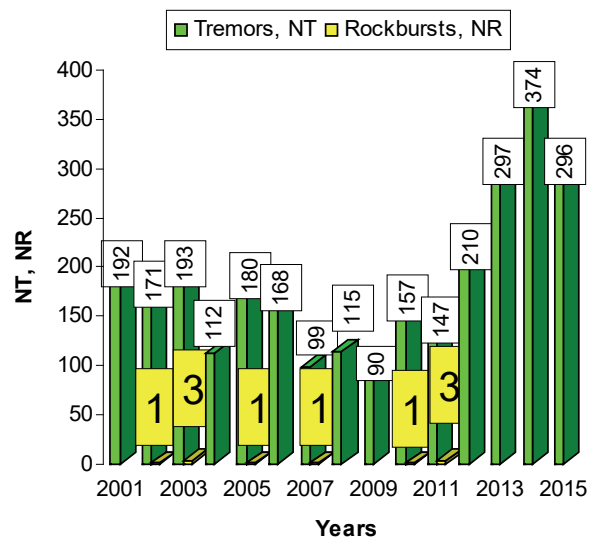

e) Tremor energy $10^{8} \leq E<10^{9}$

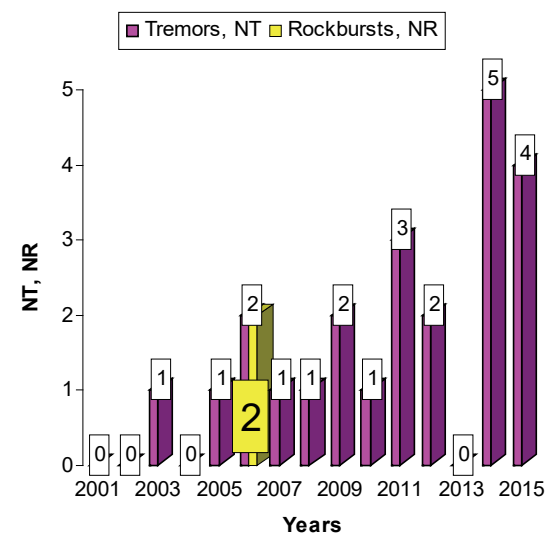

The rockburst hazard in the Jejkowice and Chwałowice Troughs is caused mainly by the great depth of exploited seams (890-1140 m).

It should be emphasized that the rockbursts recorded in the Bytom Trough occurred only in seam 510, operated by two mines: Bobrek-Centrum and Piekary. The reasons for the occurrence of rock-

b) Tremor energy $10^{5} \leq E<10^{6}$

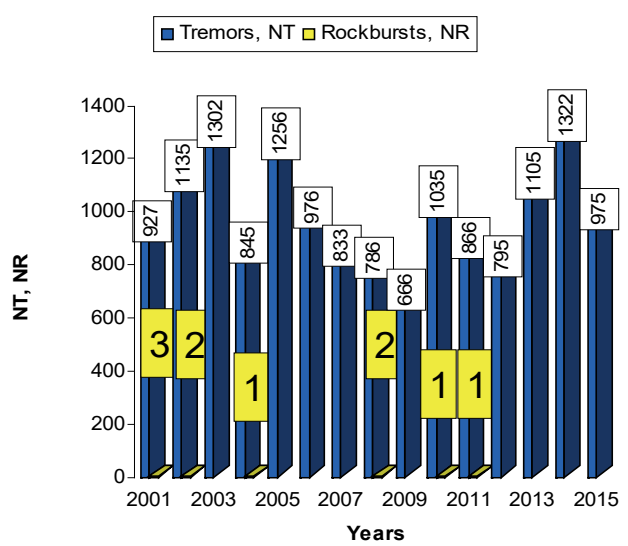

d) Tremor energy $10^{7} \leq E<10^{8}$

$\square$ Tremors, NT $\square$ Rockbursts, NR

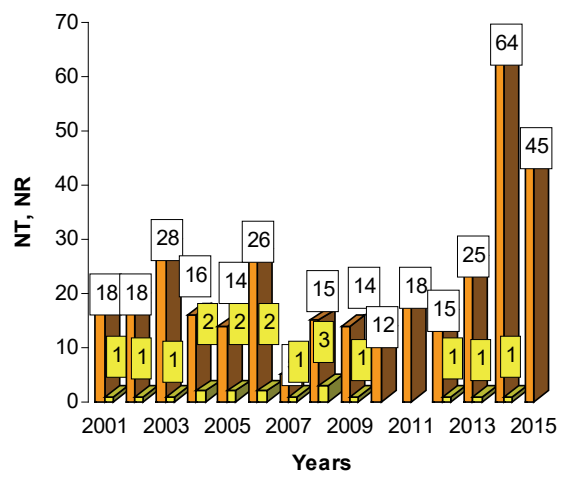

f) Tremor energy $10^{9} \leq E \leq 3 \cdot 10^{9}$

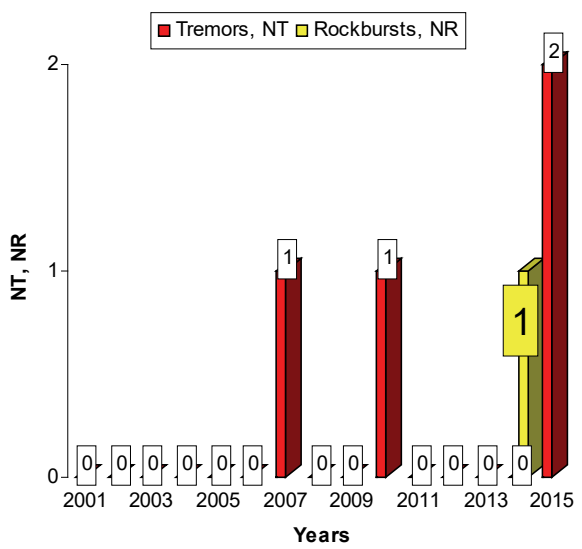

Fig. 4. Quantitative and energetic distribution of rock mass tremors in the Upper Silesian Coal Basin between 2001 and 2015 ; $\mathrm{NT}$ - number of tremors, NR - number of rockbursts 
bursts primarily include the impact of layers likely to lead to tremors and deposited in roof decks, and high compressive strength values of coal (22 MPa).

The list presented in Table 2 also shows that out of 42 rockbursts that have been recorded in the last 15 years, as many as 27 cases occurred in the seams categorized as saddle 500 , including 8 in seam 510 . The remaining 9 rockbursts were located in seams classified as stratigraphic group 400, one rockburst as 600 , and 5 rockbursts as seam 700 . Moreover, the data indicate that $52 \%$ of rockbursts occurred at depths below $840 \mathrm{~m}$, and $40 \%$ of them were recorded in areas located below $760 \mathrm{~m}$.

All the above mentioned data allow to conclude that among the five structural units, rockbursts occurred only in three of them. The area characterised by the greatest seismic activity was the Kłodnica Fault and the associated faults in the Main Saddle. The maximum number of tremors was recorded in this region, including the events that caused rockbursts. Another seismically active region characterised by a large number of rockbursts is the Jejkowice and Chwałowice Trough. The smallest number of rockbursts was recorded in the Bytom Trough. In the Main Trough, despite high seismic activity, no tremors resulting in rockbursts were recorded.

The following step of the analysis included the summary of the number of tremors and rockbursts recorded in every investigated year, and the presentation of the results against the background of individual orders of energy (Fig. 4). Table 3 shows the number of tremors and rockbursts, and accidents caused by them, with the scale of effects presented against the background of the overall output of coal. The table includes detailed data on coal extraction from seams with a high level of rockburst hazard [6].

The data presented in Fig. 4a and in Table 3 show that in 2001, 1137 tremors occurred, including 3 rockbursts. In the next two years the number of tremors increased, however, the number of tremors -4 , is similar. In 2004 only 973 tremors occurred, including 3 that caused rockbursts. Another increase in the number of tremors was recorded in 2005 (1451 tremors, 3 rockbursts), whereas between 2006 and 2009 a declining trend in the number of tremors was recorded. In 20085 rockbursts occurred, despite a relatively small number of tremors (917). In 2010, 1/3 more tremors were recorded in relation to 2009 , and only 2 resulted in rockbursts. Later, between 2011 and 2012, a decrease in the number of tremors was observed, it mainly included events of $10^{5} \mathrm{~J}$ energy (Fig. 4b), resulting in a decrease in the total number of tremors. In these years 2 and 4 rockbursts were recorded, respectively. The number of tremors increased also in 2013 and 2014. The number of tremors was 1427 and 1765, respectively.

It should be emphasized that the number of tremors (1765) in 2014 was the maximum amount during the investigated period covering 15 years. In 2015, 443 fewer tremors occurred in comparison to the preceding year.

Table 3. List of coal extractions, number of high-energy tremors, number of rockbursts, and accidents in the mines of USCB between 2001 and 2015

\begin{tabular}{|c|c|c|c|c|c|c|}
\hline \multirow{2}{*}{ Year } & \multirow{2}{*}{$\begin{array}{l}\text { Total } \\
\text { output, } \\
\text { million } \\
\text { tonnes }\end{array}$} & \multirow{2}{*}{$\begin{array}{c}\text { Output } \\
\text { from seams } \\
\text { with rockburst } \\
\text { hazard, million } \\
\text { tonnes }\end{array}$} & \multirow{2}{*}{$\begin{array}{c}\text { No. of } \\
\text { tremors } \mathrm{N} \\
\text { of } E \geq 10^{5} \mathrm{~J} \\
\text { energy }\end{array}$} & \multirow{2}{*}{$\begin{array}{l}\text { No. of } \\
\text { rockbursts } \\
\text { NR }\end{array}$} & \multicolumn{2}{|c|}{$\begin{array}{l}\text { Accidents caused } \\
\text { by rockbursts }\end{array}$} \\
\hline & & & & & fatal & other \\
\hline 2001 & 102.8 & 37.6 & 1137 & 3 & 2 & 19 \\
\hline 2002 & 102.1 & 42.2 & 1324 & 4 & 3 & 17 \\
\hline 2003 & 100.4 & 41.8 & 1524 & 4 & 2 & 16 \\
\hline 2004 & 99.2 & 39.2 & 973 & 3 & 0 & 11 \\
\hline 2005 & 99.5 & 41.0 & 1451 & 3 & 1 & 12 \\
\hline 2006 & 94.5 & 42.2 & 1172 & 4 & 4 & 20 \\
\hline 2007 & 87.4 & 44.6 & 939 & 3 & 0 & 10 \\
\hline 2008 & 83.6 & 41.9 & 917 & 5 & 0 & 26 \\
\hline 2009 & 77.5 & 34.3 & 772 & 1 & 0 & 5 \\
\hline 2010 & 76.1 & 35.8 & 1206 & 2 & 2 & 12 \\
\hline 2011 & 75.5 & 34.2 & 1034 & 4 & 1 & 6 \\
\hline 2012 & 79.2 & 37.6 & 1022 & 1 & 1 & 2 \\
\hline 2013 & 76.5 & 36.9 & 1427 & 1 & 0 & 5 \\
\hline 2014 & 72.5 & 36.0 & 1765 & 1 & 0 & 0 \\
\hline 2015 & 72.2 & 37.1 & 1322 & 2 & 2 & 2 \\
\hline
\end{tabular}


Generally, the number of tremors with the highest levels of energy, $10^{7} \mathrm{~J}, 10^{8} \mathrm{~J}$ and $10^{9}$ has increased in recent years (Fig. 4d-f). The average number of tremors of $10^{7} \mathrm{~J}$ energy between 2001 to 2013 amounted to 17, whereas in the 2014 up to 64 tremors of the same energy level occurred. Over the whole 15year period, the recorded tremors included one or two rockbursts of $10^{8} \mathrm{~J}$ energy each year, with the exception of 2011, three such events, and in 2014 with up to 5 tremors (Fig. 4.2e). One tremor of $10^{9} \mathrm{~J}$ energy occurred each year between 2008 and 2010, and in 2015 - two (Fig. 4.2f). One or two rockbursts have been recorded each year in recent years.

The data in Table 3 also indicates that in recent years, despite a reduction in terms of the total extraction as compared to 2001, the production of coal from seams with a rockburst hazard was maintained at a comparable level, and almost half of the output came from deposits classified as having a high level of the rockburst hazard. As a result, the number of high-energy tremors, $10^{7} \mathrm{~J}, 10^{8} \mathrm{~J}$ and $10^{9} \mathrm{~J}$, and the number of tremors above $10^{7} \mathrm{~J}$, increased. The largest group are rockbursts with energy of $10^{7} \mathrm{~J}-17$ events out of 333 registered tremors. The recorded energy of 12 rockbursts reached $10^{9} \mathrm{~J}$. This energy range includes 2801 tremors. Subsequently 14824 tremors of $10^{5} \mathrm{~J}$ energy included 10 rockbursts and 23 tremors of $10^{8} \mathrm{~J}$ energy included 2 rockbursts. During the analysed period which covered 15 years, one out of four tremors of $10^{9} \mathrm{~J}$ energy led to a rockburst.

\section{REGIONAL ROCKBURST INDICATOR (RWT) OF UPPER SILESIAN COAL BASIN}

In connection with the drawing process of coal resources, the mines more and more often decide to conduct the exploitation of deposits in areas with faults and/or in the areas of former exploitation. The analysis of geological and mining conditions indicates that the depth of longwall operation in the Upper Silesian Coal Basin increases each year. In 1989, the average depth of the operation was $524 \mathrm{~m}$. In 2010 it reached $700 \mathrm{~m}$, and in 2015 about $760 \mathrm{~m}$. Over the past five years, the depth of exploitation has increased by about $10 \mathrm{~m}$ every year ([7], [8]). The consequence of such practice includes the increase in seismic activity and rockburst hazard, which is one of the most dangerous natural hazards in the Polish mining industry.

The indicators characterising the so-called rockburst susceptibility of a given region were developed on the basis of the list of the amount and energy value of rockbursts and compared to the seismic activity occurring in the investigated structural areas.

The indicators include the Rockburst Probability Indicator PT and the Regional Rockburst Indicator RWT (Table 4). The Rockburst Probability Indicator (PT) was calculated from the number of rockbursts as compared to the number of tremors $(\mathrm{PT}=\mathrm{NT} / \mathrm{NW})$ [3]. The Regional Rockburst Indicator (RWT) determines the total energy of rockbursts (Et) as compared to the total energy of tremors $(\mathrm{EW}),(\mathrm{RWT}=\mathrm{ET} / \mathrm{EW})$.

The Regional Rockburst Indicator (RWT), was calculated based on the total energy of all recorded tremors $\left(E \geq 10^{5} \mathrm{~J}\right)$ against those that caused rockbursts in the region of Silesia. The Bytom Trough, and Jejkowice and Chwałowice Troughs are characterised by the obtained value of $\mathrm{RWT}_{\text {BT,JCT }}=0.007$. The $\mathrm{RWT}_{\mathrm{MS}}$ indicator of 0.234 defines the conditions of seismic activity and rockbursts in the Main Saddle of the Upper Silesian Coal Basin.

Although the Regional Rockburst Indicator for Jejkowice and the Bytom Trough of approx. 0.007, is comparable, its value is much lower than the indicator of 0.234 estimated for the Main Saddle. Despite that, the results should be subject to further and more detailed analysis due to the significant number of rock-

Table 4. List of rockburst indicators that occurred between 2001 and 2015

for structural units of the Upper Silesian Coal Basin

\begin{tabular}{|l|c|c|c|c|c|c|c|}
\hline \multicolumn{1}{|c|}{ Area } & $\begin{array}{c}\text { Number } \\
\text { of rockbursts } \\
\text { NT }\end{array}$ & $\begin{array}{c}\text { Number } \\
\text { of tremors } \\
\text { NW }\end{array}$ & $\begin{array}{c}\text { Rockbursts total } \\
\text { energy ET, J }\end{array}$ & $\begin{array}{c}\text { Tremor } \\
\text { total energy } \\
\text { EW, J }\end{array}$ & $\begin{array}{c}\text { Average depth } \\
\text { of rockbursts/ } \\
\text { depth range } \\
\text { of rockbursts, } \mathrm{m}\end{array}$ & $\begin{array}{c}\text { Rockburst } \\
\text { Probability } \\
\text { Indicator } \\
\text { rockbursts, } \\
\text { PT }=\mathrm{NT} / \mathrm{NW}\end{array}$ & $\begin{array}{c}\text { Regional } \\
\text { Rockburst } \\
\text { Indicator, } \\
\text { RWT }=\mathrm{ET} / \mathrm{EW}\end{array}$ \\
\hline Main Saddle (MS) & 28 & 8164 & $4.78 \cdot 10^{9}$ & $2.04 \cdot 10^{10}$ & $800 / 585-930$ & 0.00343 & 0.234314 \\
\hline Bytom Trough (BT) & 4 & 1492 & $4.02 \cdot 10^{7}$ & $5.48 \cdot 10^{9}$ & $930 / 890-1140$ & 0.00268 & 0.007336 \\
\hline $\begin{array}{l}\text { Jejkowice and } \\
\text { Chwałowice Basin (JCT) }\end{array}$ & 10 & 2991 & $3.77 \cdot 10^{8}$ & $5.55 \cdot 10^{9}$ & $1009 / 550-1150$ & 0.00334 & 0.006793 \\
\hline
\end{tabular}

S o u r ce: Own elaboration (Patyńska). 
bursts (10 events) which occurred in the Jejkowice Trough.

An important parameter indicating which of the selected structural units of USCB should be subject to further and more detailed study during the assessment of the rockburst hazard, in terms of the occurrence of tremors that would lead to a rockburst, is the level of the Probability of Rockburst PT. The calculations show (Table 4) that the probability levels (PT) are practically identical for the Main Saddle $\mathrm{PT}_{\mathrm{MS}}=$ 0.00343 and the Jejkowice Trough, $\mathrm{PT}_{\mathrm{JCT}}=0.00334$.

Despite the comparable values of the total energy of tremors recorded within the area of the Bytom Trough $\left(5.48 \cdot 10^{9} \mathrm{~J}\right)$ and the Jejkowice and Chwałowice Troughs $\left(5.55 \cdot 10^{9} \mathrm{~J}\right)$, the latter region is characterised by the increased possibility of tremors due to the increasing number of tremors with higher energy values.

The energy analysis of tremors which caused rockbursts, in relation to the total number of tremors, shows that:

- Bytom Trough -4 rockbursts of total energy ET = $4.02 \cdot 10^{7} \mathrm{~J}$; average energy of a tremor that caused a rockburst was about $1.01 \cdot 10^{7} \mathrm{~J} ; 1.492$ - the total number of tremors

- Jejkowice and Chwałowice Troughs - 10 rockbursts of total energy ET $=3.77 \cdot 10^{8} \mathrm{~J}$; average energy of a tremor that caused a rockburst was about $3.77 \cdot 10^{7} \mathrm{~J} ; 2.991$ - the total number of tremors.

Thus, in terms of the rockburst hazard in the previously mentioned regions, the average energy of tremors that had resulted in a rockburst was comparable.

The Probability of Rockburst indicators: Bytom Trough $\left(\mathrm{PT}_{\mathrm{BT}}=0.00268\right)$ and Jejkowice Trough $\left(\mathrm{PT}_{\mathrm{JCB}}=0.00334\right)$ are comparable despite the fact that the number of rockbursts and tremors in the Jejkowice and Chwałowice Troughs was twice as high as in the Bytom Trough (Fig. 5).

Therefore, both the seismic hazard and rockburst hazard, can be more precisely defined using the Regional Rockburst Indicator (RWT) which indicates a significant share of tremors and rockbursts on the basis of their seismic energy.

Table 1 and 4 show that the Regional Rockburst Indicator applies only to the three structural units of the Upper Silesian Coal Basin. The maximum value is reached with respect to the recorded seismic activity and the number of tremors that had caused rockbursts in the exploitation areas of mines located within the Main Saddle. The regions that follow include: Bytom Trough, Jejkowice Trough, and Jastrzębie Fold Trough. They are characterised by a substantially lower value of the RWT indicator. It should be also emphasized that the depth of tremors occurring in different regions of USCB does not correlate with the values of the Regional Rockburst Indicator (RWT).

Summing up the above, it should be stressed that the research shows that between 2001 and 2015 the rockburst hazard in the USCB mines included only the three indicated areas and did not depend on the depth of mining works.

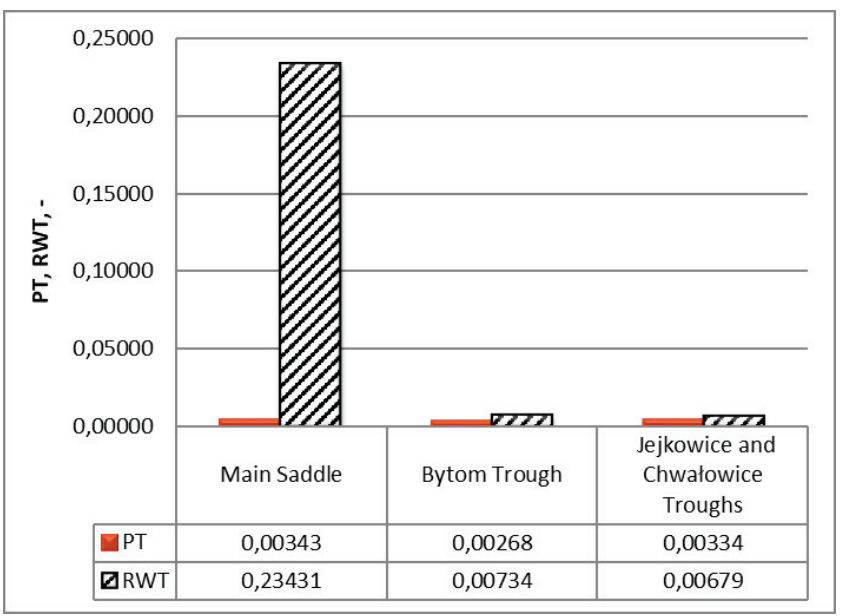

Fig. 5. Distribution of Regional Rockburst Indicators (RWT, -) against Rockburst Probability (PT, -)

in different regions of Upper Silesian Coal Basin

\section{CONCLUSIONS}

The analysis of the tremors and rockbursts catalogue stored in the Central Mining Institute's archive allowed to conclude that:

- seismic activity occurred in five regions of USCB, representing the following structural units: Bytom Trough, Main Saddle, Main Trough, Kazimierz Trough, Jejkowice and Chwałowice Troughs,

- in general, the activity was subject to change and depended on the intensity of mining works and diverse mining and geological conditions of the region,

- between 2001 and 2015, despite the reduction of total exploitation, the output from deposits with a high level of rockburst hazard increased,

- approximately $51 \%$ of output came from mining deposits classified as the areas of rockburst hazard, which resulted in an increase in the number of high-energy tremors, $10^{7} \mathrm{~J}, 10^{8} \mathrm{~J}$ and $10^{9} \mathrm{~J}$, and had a large impact on the level of the rockburst hazard,

- between 2001 and 2015, 42 rockbursts occurred, and in this group 20 were characterised by energy above $10^{7} \mathrm{~J}$, 
- rockbursts occurred in only three out of the five structural units: Main Saddle, Bytom Trough, Jejkowice and Chwałowice Troughs,

- the area characterised by the greatest seismic activity was the Kłodnica Fault and the associated faults in the Main Saddle. The maximum number of tremors was recorded also in this region, including the events which caused rockbursts,

- another seismically active region characterised by a number of rockbursts are the Jejkowice and Chwałowice Troughs,

- the area with the smallest number of rockbursts is the Bytom Trough,

- in the Main Trough, despite high seismic activity, no tremors resulting in rockbursts were recorded.

The list of seismic activity related issues and rockbursts that occurred in individual regions was used to develop the so called Regional Rockburst Indicator (RWT) which determines the level of rockburst hazard.

The relatively high value of RWT for the Main Saddle $\left(\mathrm{RWT}_{\mathrm{MS}}=0.234\right)$ indicates a very high rockburst hazard.

The Bytom Trough, and the Jejkowice and Chwałowice Troughs are characterised by lower RWT values $\left(\mathrm{RWT}_{\mathrm{BT}}\right.$, ЈСB $\left.=0.007\right)$. The detailed analysis of the mining and geological conditions of tremors will serve as the basis for the further analysis of stratigraphic units selected on the basis of the RWT indicator and will include:

- Main Saddle (MS),

- Bytom Trough (BT),

- Jejkowice and Chwałowice Trough (JCT).

\section{ACKNOWLEDGMENTS}

The article was developed on the basis of the Catalogue of Strong Mining Tremors of Upper Silesian Coal Basin developed in the Department of Geology and Geophysics at the Central
Mining Institute, and the Catalogue of Rockbursts stored in the Department of Rockburst and Rock Mechanics at Central Mining Institute.

\section{REFERENCES}

[1] BuŁa Z., ŻABA J., HABRYN R., Tectonic regionalization of Poland - Southern Poland (Upper Silesian Block, Małopolska Block), Przegląd Geologiczny, 2008, 56, No. 10, 912-920.

[2] Kotas A., Views on the structural evolution of Upper Silesia Coal Basin, [in:] Conference materials on: Tectonics of Upper Silesian Coal Basin, PIG, Sosnowiec 1985, 17-41.

[3] KonOPKo W., PATYŃSKA R., Warunki występowania tapnięć $w$ kopalniach wegla kamiennego (Conditions of occurrence of rockbursts in coal mines), Przegląd Górniczy, 2008, Vol. 1, 12-17.

[4] LURKA A., STEC K., Charakterystyka i sejsmologiczne metody analizy aktywności sejsmicznej Górnośląskiego Zagłębia Węglowego (Characteristics and seismic methods of analysis for seismic activity of Upper Silesian Coal Basin), Przegląd Górniczy, 2015, 1, 83-93.

[5] Marcak H., MutKe G., Seismic activation of tectonic stresses by mining, Journal of Seismology, 2013, 17, 4, 1139-1148, DOI: 10.1007/s10950-013-9382-3.

[6] PATYŃSKA R. et al., Zagrożenie Tapaniami [in:] (Rockburst hazard) Raport roczny o stanie zagrożeń naturalnych i technicznych $w$ górnictwie węgla kamiennego, Central Mining Institute, Katowice, 2002-2016.

[7] PATYŃSKA R., Uwarunkowania górniczo-geologiczne eksploatacji pokładów zagrożonych tapaniami w latach 1987-2007 (Mining and geological conditions of exploitation of seams with burst hazard between 1987 and 2007), Wydawnictwo IGSMiE PAN, Gospodarka Surowcami Mineralnymi, Kwartalnik, Vol. 24, Brochure, 2/3, Kraków 2008, 227-243.

[8] PATYŃSKA R., The consequences of the rockburst hazard in the Silesian Companies in Poland, Acta Geodynamica et Geomaterialia, Academy of Sciences of the Czech Republic, 2013, Vol. 10, No. 2(170), Prague, 227-235.

[9] STEC K. et al., Zagrożenie Sejsmiczne, [in:] (Seismic hazards) Raport roczny o stanie zagrożeń naturalnych i technicznych $w$ górnictwie węgla kamiennego, Central Mining Institute, Katowice 2002-2016.

[10] SteC K., Characteristics of Seismic Activity of the Upper Silesian Coal Basin in Poland, Geophysical Journal International, Blackwell Publishing, Ltd., 2007, Vol. 168, 213-219. 